\title{
KUALITAS KEPEMIMPINAN KEPALA MADRASAH DALAM PERSPEKTIF MODEL KEPEMIMPINAN YANG MELAYANI DI MADRASAH ALIYAH SE-KABUPATEN KULON PROGO
}

\author{
Siti Nurhayati \\ Program Pasca Sarjana \\ Universitas Muhammadiyah Yogyakarta \\ E-mail: siti.nurha69@gmail.com
}

\begin{abstract}
Abstrak
Penelitian ini bertujuan (1) mengetahui pemahaman kepala madrasah tentang model kepemimpinan yang melayani (2) mengetahui prinsip-prinsip model kepemimpinan yang melayani terimplementasi dalam prioritas kerja kepala madrasah (3) mengetahui peluang pengembangan model kepemimpinan yang melayani di Madrasah Aliyah se-Kabupaten Kulon Progo. Jenis penelitian ini deskriptif kualitatif, Data penelitian diperoleh dari empat Madrasah Aliyah di Kabupaten Kulon Progo dengan sasaran informan empat Kepala Madrasah Aliyah di Kulon Progo. Hasil penelitian ini yaitu: 1) Pemahaman kepala madrasah tentang kepemimpinan yang melayani cukup baik, 2) Prinsip-prinsip model kepemimpinan yang melayani terimplentasi dalam praktek kerja kepala madrasah baik, 3) Peluang pengembangan model kepemimpinan yang melayani kepala madrasah aliyah baik. Penelitian inimemberikan kontribusi peran kepala madrasah sebagai leadership dapat melaksanakan sikap/perilaku yang melayani dalam mewujudkan program madrasah.
\end{abstract}

Kata kunci: kepemimpinan yang melayani, kepala madrasah

\begin{abstract}
This study aims to (1) find out the understanding of the madrasa chief about the leadership model that serves (2) knowing the principles of leadership models that serve implemented in the priority of the headmaster's work (3) knowing the opportunities for developing leadership models serving at the Aliyah Madrasah in Kulon Progo Regency. The type of this research was descriptive qualitative. The research data was obtained from four Aliyah Madrasas in Kulon Progo Regency with the target of four informants from the Head of Aliyah Madrasah in Kulon Progo. The results of this study are: 1) The principals' understanding of leadership that serves quite well, 2) The principles of leadership models that are served are implemented in good work practices of the headmaster, 3) Opportunities for developing leadership models that serve good head of madrasah aliyah. This research contributes to the role of the head of the madrasa as leadership can implement the attitudes / behaviors that serve in realizing the madrasa program Keywords: serving leadership, madrasa head
\end{abstract}

\section{Info Artikel}

Diterima Februari 2019, disetujui Maret 2019, diterbitkan Juni 2019 


\section{PENDAHULUAN}

Kepala madrasah perlu meningkatan kualitas pendidikan sehingga pendidikan akan berjalan dengan tertib dan dinamis, berkomitmen, berwawasan luas mengerti kedudukan madrasah di masyarakat, mengenal badan-badan dan lembaga-lembaga masyarakat yang menunjang pendidikan, mengenal perubahan sosial, ekonomi, politik masyarakat, membantu guru mengembangkan guru-guru untuk meningkatkan kinerja guru dalam pengajaran dan pembelajaran di kelas agar kegiatan belajar mengajar dapat berjalan dengan efektif.

Kenyataan yang terjadi adalah adanya krisis kepemimpinan di suatu madrasah hal ini disebabkan oleh ketidakberdayaan kepala madrasah. Ketidakberdayaan ini dapat melalui tindakan dalam mengemban amanah jabatan kepala madrasah yang bertindak berdasarkan keinginan diri sendiri, sementara kondisi tata kelola organisasi yang tidak baik semakin menunjukkan betapa rendahnya keefektifandan kearifan kepemimpinan itu.Dewasa ini isu yang paling sensitif terkait dengan pendidikan; mutu pendidikan, relevansi pendidikan, akuntabilitas, profesionalisme, efisiensi, debirokrasi dan perilaku pemimpin pendidikan. Krisis kepemimpinan berakibat banyak orang yang menderita, tidak dapat menikmati hidup dalam pekerjaan ya serta banyak biaya yang dikeluarkan untuk mengobati sakit emosional ditempat kerja.

Kondisi inilah memunculkan bagaimana seharusnya menjadi pemimpin yang benar-benar bisa memimpin. Pada tahun1970 dipelopori oleh Robert Green leaf dengan teorinya servant leadhership (Kepemimpinan yang melayani). Kepemimpinan yang melayani adalah sebuah filosofi kepemimpinan kharismatik yang prinsip utamanya adalah the great leader isseenas servant first. Prinsip ini pelayanan kepada orang lain adalah utama daripada kepentingan pelayanan pada diri sendiri dengan mendorong, mengembangkan atmosfir kerja dan membangun komunitas kerja tim.Filosofi menjadi pelayan inilah yang sering hilang dalam konteks organisasi madrasah yang cenderung birokratik mekanistik, madrasah kehilangan pelajaran menghargai manusia sebagai guru, staf karyawan, siswa dan pihak luar madrasah dengan prioritas yang tinggi. Fokus servant leadhership adalah dapat melayani, keseluruhan dari pribadi melayani dan berperilaku sesuai norma agama.

Model kepemimpinan yang melayani (servant leadhership) yang bermula dalam karya tulis Greenleaf $(1970,1972,1977)$ tujuan utamanya menciptakan organisasi yang 
sehat yang mendukung pertumbuhan individual, memperkuat kinerja organisasi, dan pada akhirnya, menciptakan dampak positif bagi masyarakat.

Kehadiran kepala madrasah sebagai sosok yang memberi $\neg$ kan perhatian, pelayanan, dan teladan kepada bawahannya diyakini akan meningkatkan komitmen guru sehingga guru merasa memiliki dan bertanggungjawab penuh serta men $\neg$ dukung kegiatan yang diprogramkan oleh kepala madrasah.

Penelitian ini berguna untuk:

a. Psikologi pendidikan Islam, tentang kualitas kepemimpinan kepala madrasah aliyah dalam presfektif kepemimpinan yang melayani.

b. Bagi kepala madrasah, memberi pengetahuan untuk kepemimpinan yang melayanidalam rangka mutu pendidikan.

c. Bagi stakeholders pendidikan, pengetahuan dalam menyusun dan merencanakan kualitas pendidikan madrasah dengan menerapkan kepemimpinan yang melayani.

\section{KEPEMIMPINAN}

Pemimpin berasal dari kata "leader" yang merupakan bentuk benda dari "to lead" yang berarti memimpin. Menurut Alben kepemimpinan adalah suatu proses menggerakkan, mempengaruhi dan membimbing orang lain dalam rangka mencapai tujuan.Kepala madrasah harus mampu menjadi agen utama perubahan (Change agent) yang mampu mendorong dan mengelola agar semua warga madrasah dan berbagai pihak yang berkepentingan, termotivasi dan berperan aktif dalam perubahan tersebut. Peran agen perubahan adalah sebagai catalyst, solution givers, process helpers dan resources linkers.

Kepemimpinan merupakan kemampuan seseorang dalam mempengaruhi orang lain, menggerakan, mengarahkan, membimbing, membina, memberikan teladan, memberikan dorongan, memberikan bantuan dan melindunngi individu atau kelompok, serta kemampuan untuk mengarahkan tingkah laku individu atau kelompok untuk memiliki kemampuan atau keahlian khusus dalam bidang yang diinginkan oleh kelompoknya, sehingga bawahan dengan senang hati melaksanakan tugas yang diberikan untuk mencapai tujuan yang telah ditentukan. 


\section{MODEL KEPEMIMPINAN}

Model kepemimpinan berlandaskan perilaku dan keterampilan seseorang kemudian membentuk gaya kepemimpinan yang berbeda. Beberapa model yang menganut pendekatan ini, di antaranya adalah sebagai berikut.

a. Model kepemimpinan Kontinum berupa Otokratis-Demokratis. Tannenbaun dan Schmidt dalam Hersey dan Blanchard (1994) menyatakan bahwa cara pemimpin mempengaruhi pengikutnya melalui perilaku otokratis dan perilaku demokratis..

b. Model Kepemimpinan Ohio. Dalam penelitiannya Universitas Ohio menghasilkan teori dua faktor tentang gaya kepemimpinan yaitu struktur inisiasi dan konsiderasi (Hersey dan Blanchard, 1992).

c. Model Kepemimpinan Likert (Likert's Management System). Likert dalam Stoner (1978) menyatakan bahwa dalam model kepemimpinan dapat dikelompokkan dalam empat sistem, yaitu sistem otoriter, otoriter yang bijaksana, konsultatif, dan partisipatif.

d. Model Kepemimpinan Managerial Grid. Blake dan Mouton dalam Robbins (1996) menyatakan model kepemimpinan yang ditinjau dari perhatian tugas dan perhatian pada orang.

e. Model Kepemimpinan Kontingensi. Model kepemimpinan kontingensi dikembangkan Fiedler menyatakan ada dua gaya yaitu gaya yang berorientasi pada tugas dan gaya yang berorientasi pada hubungan manusia.

f. Model Kepemimpinan Tiga Dimensi. Model kepemimpin oleh Redin. Model ini merupakan pengembangan yang dikembangkan oleh Universitas Ohio dan model Managerial Grid.

\section{PRINSIP - PRINSIP KEPEMIMPINAN}

Atmadja menyatakan bahwa prinsip kepemimpinan adalah kualitas personal yakni tidak dinilai dari karakter personal, tapi lebih ditekankan pada fungsi, peranan, atau perilaku yang ditampilkan.Sedangkan prinsip-prinsip kepemimpinan menurut Stephen R.Coney yang dikutip Rivai sebagai berikut :

a. Seorang yang belajar seumur hidup

b. Berorientasi pada pelayanan: Pemimpin yang berprinsip melihat kehidupan ini sebagai misi, bukan karier. Ukuran keberhasilan mereka adalah bagaimana mereka 
bisa menolong dan melayani orang lain. Inti kepemimpinan yang berprinsip adalah kesediaan untuk memikul beban orang lain.

c. Membawa energi positif : Secara fisik, pemimpin yang berprinsip memiliki air muka yang menyenangkan dan bahagia.

Hampir sama dengan Toman Sony Tambunan prinsip-prinsip kepemimpinan yaitu:

a. Melayani ; Prinsip memberikan pelayanan yang baik sebagai tujuan tama. Pemimpin yang efektif harus bisa melayani guna memenuhi kebutuhan dan keinginan, sehingga meningkatkan kesejahteraan orang-orang yang dipimpinnya.

b. Membuat keputusan; Membuat keputusan merupakan fungsi-fungsi dasar dari berpikir, dimana proses penggunaan pikiran dalam mengarahkan pada suatu tindakan untuk menetapkan suatu pilihan.

c. Keteladanan

d. Bertanggung jawab

e. Bekerja sama

f. Menciptakan perubahan

\section{FUNGSI KEPEMIMPINAN}

Kepemimpinan menekankan pada usaha mencapai tujuan bersama-sama dengan orang lain melalui kepengikutan. James M Kouzes (1995) dan David W. Johnson (1997) fungsi kepemimpinan: [1] Menantang proses dan status quo. [2] Menyamakan visi bersama. [3] Memberdayakan anggota melalui tim kerja kooperatif. [4] Memberikan contoh. [5] Membangkitkan jiwa untuk terus memperbaiki keahlian konseptual, teknis dan keahlian interpersonal.

Fungsi utama dari kepemimpinan adalah memimpin, maka kemampuan untuk mempengaruhi orang adalah hal yang penting. Melakukan tindakan-tindakan efektif dalam memotivasi guru membuat orang tersebut melakukan apa yang diinginkan adalah sebuah keharusan, sebaliknya melakukan tindakankontra produktif yang dapat menjatuhkan motivasi adalah tindakan yang harus dihindari. 


\section{FAKTOR-FAKTOR YANG MEMPENGARUHI KEPEMIMPINAN}

Kepemimpinan merupakan fenomena unik, Terdapat 4 faktor kepemimpinan yakni. 1) Pemimpin, 2) Pengikut, 3) Situasi, 4) Komunikasi. Kepemimpinan yang melayani menurut Liden, Wayne, Zhao, \& Henderson (2008) menyebutkan 3 hal yang mempengaruhi faktor Servant Leadership, yaitu Context and Culture adalah kondisi dalam konteks organisasi dan dimensi budaya organisasi. Leader Attributes, pengaruh karakter kemampuan pemimpin menerapkannya dalam Servant Leadership (mencakup pengembangan moral dan kecerdasan emosional) dan Follower Receptivity yaitu kekuatan penerimaan karyawan, merupakan kondisi yang sesuai harapan karyawan, maka Servant Leadership akan memberi efek positif pada kinerja dan OCB

\section{KEPEMIMPINAN KEPALA MADRASAH}

Wahjo Sumidjo mengartikan kepala madrasah adalah seorang tenaga fungsional guru yang diberi tugas untuk memimpin lembaga madrasah tempat diselenggarakan proses belajar mengajar atau tempat terjadinya interaksi antara guru yang memberi pelajaran dan murid yang menerima pelajaran.

Kepala madrasah dituntut sebagai jabatan profesional dalam memimpin organisasi madrasah dengan tugas mengelola semua sumber organisasi dan bekerjasama dengan guru-guru untuk mencapai tujuan pendidikan. Kegiatan lembaga pendidikan madrasah disamping diatur oleh pemerintah, sebagian besar ditentukan oleh aktivitas kepala madrasahnya. Kepala madrasah merupakan kunci kesuksesan madrasah dalam mengadakan perubahan. Sehingga kegiatan meningkatkan dan memperbaiki program dan proses pembelajaran di madrasah sebagian besar terletak pada diri kepala madrasah itu sendiri.

\section{TEORI DALAM KEPEMIMPINAN YANG MELAYANI}

Teori atau pandangan tentang pemimpin yang melayani Greenleaf dengan Servant Leadhership yakni dimulai dengan perasaan alamiah bahwa kita ingin melayani lebih dulu, lalu pilihan yang disadari membawa seseorang berharap untuk memimpin.

Sebagaimana Greenleaf menyatakan:

The servant-leader is servant first. It begins with the natural feeling that one wants to serve. Then conscious choice brings oneto aspire to lead. The best test is: do those served grow as persons: do they, while being served, become 
healthier, wiser, freer, more autonomous, more likely themselves to become servants?And, what is the effect on the least privileged insociety; will they benefit, or, at least, not be further deprived? (Greenleaf, 1970 )

Kepemimpinan yang melayani adalah kepemimpinan yang menekankan pada pelayanan kepada orang lain, dengan melakukan pendekatan layanan secara utuh kepada pekerjaan, kemasyarakatan dan pemimpin membuat keputusan bersama-sama dan berbagi dengan pihak lain.

\section{PERILAKU KEPEMIMPINAN YANG MELAYANI}

Kepemimpinan yang melayani dapat diketahui dengan perilaku untuk melayani Kepemimpinan yang melayani diindikatorkan oleh spears dari Greenleaf dengan aspek Karakter dari pemimpin yang melayani (servant Leadhership) menurut Spears adalah: 1) Mendengarkan, 2) Empati, 3) Menyembuhkan, 4) Persuasi, 5) Konseptualisasi, 6) Peramalan, 7) Menuju masa depan, 8) Tugas untuk mengurus, 9) Komitmen untuk pertumbuhan orang-orang, 10) Membangun komunitas.

Van Dierendonck menyatakan dalam penelitiannya memberikan enam karakteristik kunci mengenai perilaku kepemimpinan yang melayani dengan kombinasi kesimpulan dari hasil karya Greenleaf dan beberapa tokoh penulis kepemimpinan yang melayani, Servant Leadership ini dapat dikelompokkan menjadi 6 item utama; 1) Memberdayakan dan mengembangkan orang, 2) Kerendahan hati, 3) Keaslian, 4) Penerimaan Interpersonal, 5) Memberikan arahan, 6) Mengurus.

Sedangkan menurut menurut Dennis menyatakan kontruksi servant leadership yaitu terdiri dari: 1) Kasih Sayang, 2)Pemberdayaan (Empowerment), 3)Visi (Vision), 4) Kerendahan hati (Humility), 5) Kepercayaan (Trust). Dennis menyatakan kontruksi servant leadership sedangkan Model kepemimpinan yang melayani (servant leadhership) menurut pakar kepemimpinan seperti Liden, Wayne (2008) untuk mengembangkan 7 perilaku pemimpin yang melayani; membentuk konsep, memulihkan emosi, mengutamakan pengikut, membantu pengikut tumbuh dan sukses, berperilaku secara etis, memberdayakan, menciptakan nilai untuk masyarakat.

John Maxwell ada tingkatan dalam kepemimpinan yang melayani. John Maxwell dalam buku Daryanto menyatakan 5 level kepemimpinan yang melayani yaitu posisi, hubungan dengan orang lain, Produk/hasil, peningkatan kesejahteraan anggota 
organisasi, dan kehormatan. John Maxwell, membagi kepemimpinan menjadi lima level yang harus dilewati. Menurutnya, jika kepemimpinan itu diibaratkan seperti anak tangga, terdapat lima tangga utama yang harus dilewati oleh para pemimpin $\neg$ an di dalam organisasi.

Berikut adalah tabel teori kepemimpinan yang melayani menurut para ahli.

Tabel 1.

Teori Kepemimpinan Yang Melayani

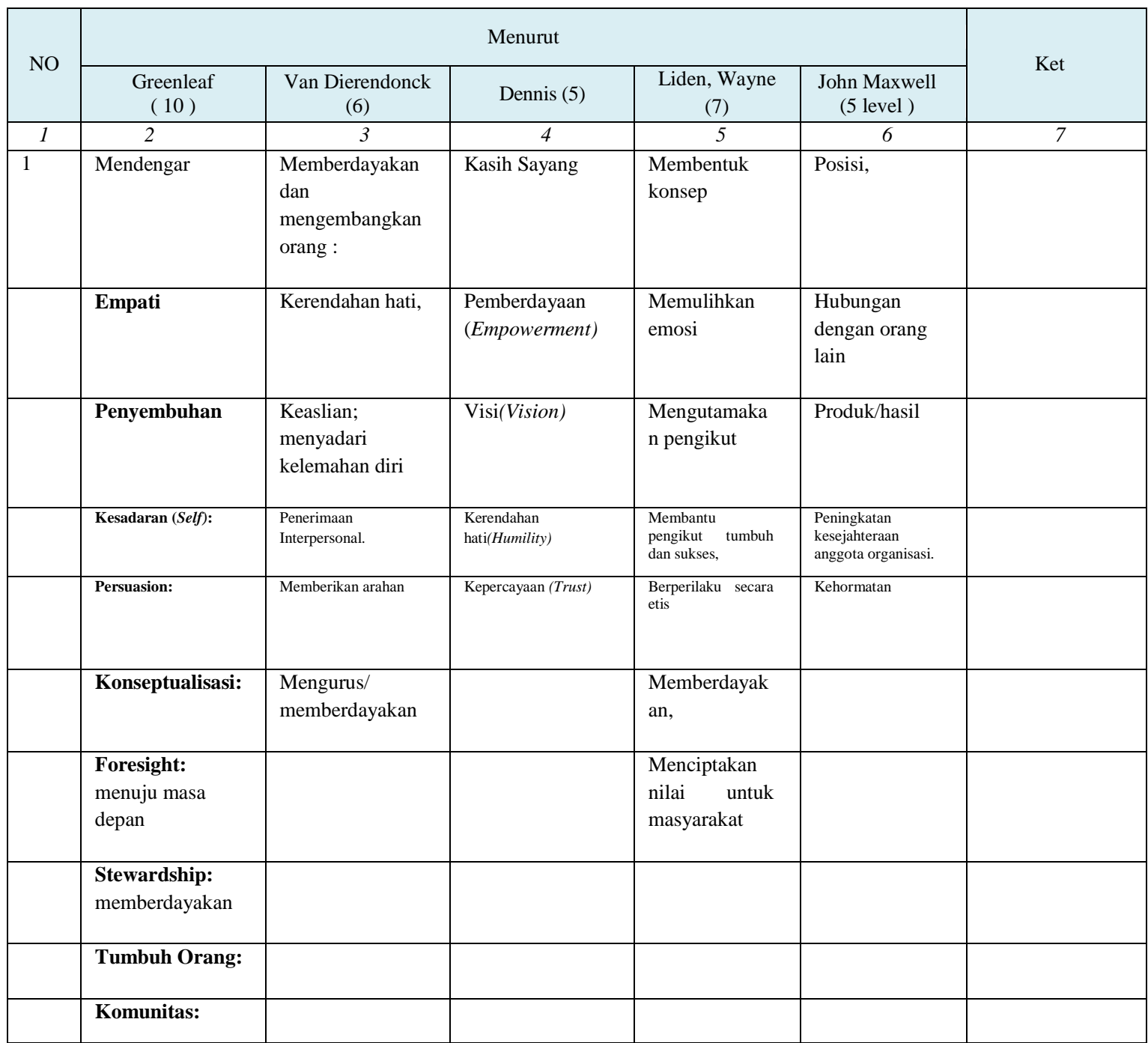

\section{KEPEMIMPINAN YANG MELAYANI DIBIDANG PENDIDIKAN}

\section{(MADRASAH)}

Kepemimpinan yang melayani dapat juga dilaksanakan selain pada organisasi dapat juga pada lembaga pendidikan sebagaimana pendapat kepemimpinan yang melayani sebagai guru menurut Laub mendefinisikan kepemimpinan pelayan sebagai 
pemahaman dan praktek kepemimpinan yang menempatkan kebaikan mereka memimpin lebih dari kepentingan diri pemimpin. Kepemimpinan pelayan mempromosikan nilai dan pengembangan orang, pembangunan masyarakat, praktek keaslian, yang memberikan kepemimpinan untuk kebaikan mereka dipimpin dan pembagian kekuasaan dan status untuk kebaikan bersama dari setiap individu, total organisasi dan mereka yang dilayani oleh organisasi.

Pada umumnya pemimpin kepala madrasah masih banyak yang belum menerapkan model kepemimpinannya secara optimal dalam tugasnya. Kepala madrasah masih memperlakukan bawahannya dengan sama tanpa memperhatikan perbedaan individual antara guru yang satu dengan guru yang lainnya. Kepala madrasah belum menerapkan gaya kepemimpinan yang efektif dan efisien dalam kepemimpinannya di madrasah. Kepala madrasah dituntut untuk mampu memperhatikan dan memberikan perlakuan yang berbeda sesuai dengan kematangan bawahannya.

Layanan pembelajaran merupakan aspek utama organisasi madrasah. Madrasah yang efektif senantiasa responsive dan adaptif terhadap perkembangan lingkungan yang kompleks dan penuh ketidakpastian. Oleh karena itu, layanan pembelajaran madrasah efektif pada penciptaan madrasah sebagai organisasi pembelajar.

\section{METODE PENELITIAN}

\section{Jenis Penelitian}

Penelitian ini merupakan penelitian kualitatif. Pendekatan kualitatif sebagai prosedur penelitian yang menghasilkan data deskriptif berupa kata-kata tertulis atau lisan dari orang-orang dan perilaku yang diamati. Bertujuan untuk memahami (understanding) dunia makna yang disimpulkan dalam perilaku masyarakat (guru) menurut perspektif masyarakat (lingkungan madrasah) itu sendiri karena penelitian ini bersifat understanding, maka pelaporannya bersifat diskriptif dan naratif.

\section{Sampel Penelitian}

Sampel penelitian adalah kepala madrasah aliyah di Kulon Progo. Jumlah sampel penelitian kualitatif lebih sedikit dibandingkan dengan penelitian kuantitatif, dan penelitiannya lebih mengarah penelitian proses daripada produk serta kasus dalam penelitian dibatasi oleh satu kasus. 
Pengambilan sampel penelitian kualitatif mempergunakan purposive sampling. Arti Purposive sampling yaitu sampel sumber data diambil berdasarkan pilihan beberapa pertimbangan seperti sumber data tersebut yang dianggap mengetahui yang kita diharapkanatau sebab sumber tersebut mempunyai kekuasaan untuk memberikan kemudahan menjelajahi obyek atau situasi yang diteliti, dengan kata lain pengambilan sampel diambil sesuai keperluan. Pada penelitian ini, peneliti mengambil 4 orang guru yang menjadi purposive sampling yaitu setiap madrasah satu orang guru yang diambil secara acak.

\section{Metode Pengumpulan Data}

Cara- cara yang ditempuh dalam penelitian dan sekaligus proses pelaksanaannya.

a. Sumber Data; Respondennya Kepala madrasah, Guru, terkait tentang Kepemimpinan kepala Madrasah dalam presfektif kepemimpinan yang melayani di Madrasah Aliyah.

b. Tehnik pengumpulan data.

1) Metode Observasi atau Metode Pengamatan

Metode ini biasanya diartikan sebagai pengamatan dan pencatatan secara sistematik secara langsung maupun tidak langsung terhadap gejala-gejala subjek yang diteliti, dengan menggunakan participant observation, artinya: peneliti juga terlibat sebagai sumber data, dalam memperoleh data yang diperlukan dalam penelitian ini.Kegiatan observasi ini penulis laksanakan untuk memperoleh data tetap tentang Kepemimpinan kepala madrasah yang melayani di Madrasah Aliyahse-Kabupaten Kulon Progo.

2) Dokumentasi

Metode ini digunakan untuk mencari data mengenai hal-hal atau variabel yang berupa catatan, transkrip, buku, surat kabar, dan sebagainya.Metode dokumentasi ini penulis gunakan untuk memperoleh data yang sudah terwujud dokumen tentang masalah-masalah yang ada hubungan dengan kepemimpinan kepala madrasah yang melayani, seperti: Supervisi kepala madrasah, catatan/bimbingan guru, dan dokumen-dokumen lain yang terkait dengan data yang diperlukan dalam penelitian ini. 


\section{3) Wawancara atau Interview}

Adapun metodeinterview yang digunakan adalah interview bebas terpimpin, yaitu:Interview bebas terpimpin adalah kombinasi antara interviewbebas dan interview terpimpin. Dalam melaksanakan interview pewawancara membawa pedoman yang hanya merupakan garis besar tentang hal-hal yang akan ditanyakan.Metode ini dimaksudkan untuk memperoleh tanggapan, pendapat, kebijakan-kebijakan dan kesan responden mengenai kepemimpinan yang melayani kepala madrasah yang dilaksanakan di Madrasah aliyah se-Kabupaten Kulon Progo

\section{HASIL DAN PEMBAHASAN PENELITIAN}

Beberapa ahli menyatakan tentang pemimpin yang melayani ada pada tabel berikut ini.

Tabel 2

Aspek kepemimpinan yang melayani dan indikator kepemimpinan yang melayani

\begin{tabular}{|c|c|c|c|c|}
\hline No. & тоКОН & MODEL/KARAKTER & KOMPETENSI & INDIKATOR \\
\hline \multirow[t]{7}{*}{1} & \multirow[t]{4}{*}{ Greenleaf } & \multirow[t]{4}{*}{ Mendengar } & \multirow{7}{*}{$\begin{array}{l}\text { - Komitmen } \\
\text { mendengarkan } \\
\text { dengan penuh } \\
\text { perhatian }\end{array}$} & - Mendengarkan tiap individu guru \\
\hline & & & & $\begin{array}{l}\text { - Mengulang apa yang telah didengar untuk } \\
\text { mendapatkan pemahaman dan keselarasan }\end{array}$ \\
\hline & & & & $\begin{array}{l}\text { - Mencari umpan balik dari permasalahan } \\
\text { tentang guru }\end{array}$ \\
\hline & & & & - Membuat keputusan penting. \\
\hline & \multirow[t]{3}{*}{ Van Dierendonck } & \multirow{3}{*}{$\begin{array}{l}\text { Penerimaan } \\
\text { interpersonal }\end{array}$} & & - Menyadari kelemahan diri seorang guru \\
\hline & & & & - Cara membantunya \\
\hline & & & & $\begin{array}{l}\text { - Mengidentifikasi masalah dan resiko dalam } \\
\text { kepemimpinan }\end{array}$ \\
\hline \multirow[t]{2}{*}{2} & Greenleaf & Penyembuhan & \multirow{2}{*}{$\begin{array}{l}\text { - Menyembuhkan diri } \\
\text { sendiri dan guru } \\
\text { serta siswa. }\end{array}$} & $\begin{array}{l}\text { - Kinerja untuk masa lalu atau kinerja yang } \\
\text { berpeluang untuk masa depan }\end{array}$ \\
\hline & Liden, Wayne & $\begin{array}{l}\text { Memulihkan } \\
\text { emosi }\end{array}$ & & $\begin{array}{l}\text { - Cara anda terjadi perselisihan pendapat } \\
\text { dengan guru }\end{array}$ \\
\hline \multirow[t]{2}{*}{3} & Greenleaf & Kesadaran $($ Self): & \multirow[t]{2}{*}{ - Menyadari diri } & $\begin{array}{l}\text { - Menyadari kelemahan diri seorang guru dan } \\
\text { cara membantunya }\end{array}$ \\
\hline & Van Dierendonck & $\begin{array}{l}\text { Keaslian; } \\
\text { menyadari } \\
\text { kelemahan diri }\end{array}$ & & $\begin{array}{l}\text { Kesadaran (Organisasi): mengidentifikasi } \\
\text { masalah dan resiko dalam kepemimpinan. }\end{array}$ \\
\hline \multirow[t]{2}{*}{4} & Greenleaf & Konseptualisasi: & $\begin{array}{l}\text { Membawa visi } \\
\text { perspektif } \\
\text { konseptualisasi } \\
\text { (membentuk ide } \\
\text { atau gambar). } \\
\end{array}$ & $\begin{array}{l}\text { - Menciptakan konsep untuk mencapai } \\
\text { kesuksesan }\end{array}$ \\
\hline & Liden, Wayne & $\begin{array}{l}\text { Membentuk } \\
\text { konsep }\end{array}$ & & - Tanggapan tentang konsep atau perencanaan \\
\hline \multirow[t]{2}{*}{5} & Greenleaf & $\begin{array}{l}\text { Foresight: menuju } \\
\text { masa depan }\end{array}$ & $\begin{array}{l}\text { Keputusan untuk } \\
\text { suatu masa depan } \\
\text { dengan berbagai } \\
\text { konsekuensi }\end{array}$ & $\begin{array}{l}\text { - Membuat keputusan untuk suatu masa depan } \\
\text { dengan berbagai konsekuensi }\end{array}$ \\
\hline & Dennis & Visi (Vision) & $\begin{array}{l}\text { Visi anda dalam } \\
\text { kepemimpinan masa } \\
\text { depan }\end{array}$ & - Visi anda dalam kepemimpinan masa depan \\
\hline 6 & Green Leaf & Stewardship: & - Memberdayakan & - Memberdayakan sumber daya seorang guru \\
\hline
\end{tabular}


Vol. 3 No. 2, Bulan Juni Tahun 2019

p-ISSN : 2541-6782, e-ISSN : 2580-6467

\begin{tabular}{|c|c|c|c|c|}
\hline No. & токон & MODEL/ KARAKTER & KOMPETENSI & INDIKATOR \\
\hline & & memberdayakan & $\begin{array}{l}\text { sumber daya } \\
\text { seorang guru }\end{array}$ & \\
\hline & Van Dierendonck & $\begin{array}{l}\text { Mengurus/Membe } \\
\text { rdayakan }\end{array}$ & $\begin{array}{l}\text { - Menumbuhkan dan } \\
\text { mengembangkan } \\
\text { seorang guru } \\
\text { menjadi baik }\end{array}$ & $\begin{array}{l}\text { - Menumbuhkan dan mengembangkan seorang } \\
\text { guru menjadi baik }\end{array}$ \\
\hline & & & $\begin{array}{l}\text { - Memberi peluang } \\
\text { baru bagi seorang } \\
\text { guru }\end{array}$ & - Memberi peluang baru bagi seorang guru. \\
\hline & Liden, Wayne & Memberdayakan & & \\
\hline \multirow[t]{3}{*}{7} & Greenleaf & Tumbuh Orang: & $\begin{array}{l}\text { - Percaya orang } \\
\text { memiliki nilai } \\
\text { intrinsik } \\
\end{array}$ & \\
\hline & Liden, Wayne & $\begin{array}{l}\text { Membantu } \\
\text { pengikut tumbuh } \\
\text { dan sukses, }\end{array}$ & $\begin{array}{l}\text { - Menumbuhkan dan } \\
\text { mengembangkan } \\
\text { seorang guru } \\
\text { menjadi baik }\end{array}$ & $\begin{array}{l}\text { - Menumbuhkan dan mengembangkan seorang } \\
\text { guru menjadi baik. }\end{array}$ \\
\hline & & & $\begin{array}{l}\text { - memberi peluang } \\
\text { baru bagi seorang } \\
\text { guru }\end{array}$ & - Memberi peluang baru bagi seorang guru. \\
\hline \multirow[t]{2}{*}{8} & Greenleaf & $\begin{array}{l}\text { Membangun } \\
\text { Komunitas: }\end{array}$ & $\begin{array}{l}\text { - Mengidentifikasi } \\
\text { madrasah/madrasah }\end{array}$ & $\begin{array}{l}\text { - Pekerjaan anda dalam menciptakan komunitas } \\
\text { masyarakat }\end{array}$ \\
\hline & Liden, Wayne & $\begin{array}{l}\text { Menciptakan nilai } \\
\text { untuk masyarakat. }\end{array}$ & $\begin{array}{l}\text { - Pekerjaan anda } \\
\text { dalam menciptakan } \\
\text { hubungan } \\
\text { kemasyarakatan }\end{array}$ & $\begin{array}{l}\text { - Pekerjaan anda dalam menciptakan hubungan } \\
\text { kemasyarakatan }\end{array}$ \\
\hline \multirow[t]{2}{*}{9} & \multirow[t]{2}{*}{ Greenleaf } & \multirow[t]{2}{*}{ Empati } & \multirow{2}{*}{$\begin{array}{l}\text { - Memahami, } \\
\text { menerima dan } \\
\text { mengakui semangat } \\
\text { khusus dan unik. }\end{array}$} & $\begin{array}{l}\text { - Memahami keaadaan sekitar dalam mengatasi } \\
\text { suatu permintaan }\end{array}$ \\
\hline & & & & - Masalah kinerja guru yang tidak fokus bekerja \\
\hline \multirow[t]{2}{*}{10} & \multirow[t]{2}{*}{ Greenleaf } & \multirow[t]{2}{*}{ Persuasion: } & \multirow[t]{2}{*}{$\begin{array}{l}\text { - Membangun } \\
\text { konsensus }\end{array}$} & $\begin{array}{l}\text { - Mempengaruhi seorang guru untuk } \\
\text { melakukan aktifitasnya }\end{array}$ \\
\hline & & & & $\begin{array}{l}\text { - Membuat konsensus atau membuat } \\
\text { keputusan yang akan dilaksanakan }\end{array}$ \\
\hline \multirow[t]{2}{*}{11} & Van Dierendonck & $\begin{array}{l}\text { Memberikan } \\
\text { arahan }\end{array}$ & $\begin{array}{l}\text { - } \text { Mempengaruhi } \\
\text { seorang guru untuk } \\
\text { melakukan } \\
\text { aktifitasnya } \\
\end{array}$ & $\begin{array}{l}\text { - Mempengaruhi seorang guru untuk } \\
\text { melakukan aktifitasnya }\end{array}$ \\
\hline & & & $\begin{array}{l}\text { - Membuat konsensus } \\
\text { atau membuat } \\
\text { keputusan yang akan } \\
\text { dilaksanakan } \\
\end{array}$ & $\begin{array}{l}\text { - membuat konsensus atau membuat keputusan } \\
\text { yang akan dilaksanakan }\end{array}$ \\
\hline 12 & Dennis & Kasih Sayang & $\begin{array}{l}\text { - } \text { Memohon guru } \\
\text { untuk melakukan } \\
\text { suatu pekerjaan }\end{array}$ & $\begin{array}{l}\text { - Memohon guru untuk melakukan suatu } \\
\text { pekerjaan }\end{array}$ \\
\hline 13 & Dennis & $\begin{array}{l}\text { Kepercayaan } \\
\text { (Trust) }\end{array}$ & $\begin{array}{l}\text { - Memberikan } \\
\text { kepercayaan pada } \\
\text { guru untuk } \\
\text { mengerjakan tugas } \\
\text { dan } \\
\text { tanggungjawabnya } \\
\end{array}$ & $\begin{array}{l}\text { - Memberikan kepercayaan pada guru untuk } \\
\text { mengerjakan tugas dan tanggungjawabnya }\end{array}$ \\
\hline 14 & Liden, Wayne & $\begin{array}{l}\text { Berperilaku secara } \\
\text { etis }\end{array}$ & - Sikap anda sehari-hari & - Sikap anda sehari-hari \\
\hline 15 & John Maxwell & Posisi & $\begin{array}{l}\text { Menempatkan posisi } \\
\text { sebagai pemimipin di } \\
\text { Madrasah }\end{array}$ & $\begin{array}{l}\text { - Menempatkan posisi sebagai pemimipin di } \\
\text { Madrasah }\end{array}$ \\
\hline 16 & John Maxwell & $\begin{array}{l}\text { Hubungan dengan } \\
\text { orang lain }\end{array}$ & $\begin{array}{l}\text { - Pekerjaan anda dalam } \\
\text { menciptakan } \\
\text { hubungan } \\
\text { kemasyarakatan }\end{array}$ & $\begin{array}{l}\text { - Pekerjaan anda dalam menciptakan hubungan } \\
\text { kemasyarakatan }\end{array}$ \\
\hline 17 & John Maxwell & Produk/hasil & $\begin{array}{l}\text { - Hasil yang telah } \\
\text { diperoleh dari model } \\
\text { kepemimpinan } \\
\end{array}$ & $\begin{array}{l}\text { - Hasil yang telah diperoleh dari model } \\
\text { kepemimpinan }\end{array}$ \\
\hline 18 & John Maxwell & $\begin{array}{l}\text { Peningkatan } \\
\text { kesejahteraan } \\
\text { anggota } \\
\text { organisasi, } \\
\end{array}$ & $\begin{array}{l}\text { - Meningkatkan } \\
\text { kesejahteraan guru- } \\
\text { guru }\end{array}$ & - Meningkatkan kesejahteraan guru-guru \\
\hline
\end{tabular}

Dipublikasikan Oleh: Program Studi Bimbingan dan Konseling 
Vol. 3 No. 2, Bulan Juni Tahun 2019

p-ISSN : 2541-6782, e-ISSN : 2580-6467

\begin{tabular}{|c|c|c|c|c|}
\hline No. & тОКОН & MODEL/ KARAKTER & KOMPETENSI & INDIKATOR \\
\hline 19 & John Maxwell & Kehormatan & $\begin{array}{l}\text { Menjaga hubungan } \\
\text { yang baik dengan } \\
\text { guru-guru di } \\
\text { madrasah }\end{array}$ & $\begin{array}{l}\text { - Menjaga hubungan yang baik dengan guru- } \\
\text { guru di madrasah }\end{array}$ \\
\hline
\end{tabular}

Berdasarkan tabel tersebut diatas maka dapat dirumuskan tentang pemahaman, prinsip-prinsip peluang kepemimpinan yang melayani berikut ini:

\section{Pemahaman Kepala Madrasah Tentang Model Kepemimpinan Yang Melayani Di}

\section{Madrasah Aliyah}

Kepemimpinan, menurut Alben kepemimpinan adalah suatu proses menggerakkan, mempengaruhi dan membimbing orang lain dalam rangka mencapai tujuan. Berikut tabel kepala madrasah dalam pemahaman kepemimpinan yang melayani.

Tabel 3.

Pemahaman Kepala Madrasah Tentang Model Kepemimpinan Yang Melayani Analisis Hasil Wawancara Dengan Kepala Madrasah

\begin{tabular}{|c|c|c|c|c|c|c|c|}
\hline No. & Aspek masalah & Karakter & $\begin{array}{l}\text { Kepala } \\
\text { MAN } 1\end{array}$ & $\begin{array}{l}\text { Kepala } \\
\text { MAN } 2\end{array}$ & $\begin{array}{l}\text { Kepala } \\
\text { MAN } 3\end{array}$ & $\begin{array}{c}\text { Kepala } \\
\text { MA DU }\end{array}$ & kesimpulan \\
\hline 1 & $\begin{array}{l}\text { Definisi kepemimpinan } \\
\text { yang melayani }\end{array}$ & $\begin{array}{l}\text {-Mendengar } \\
\text {-Penerimaan } \\
\text { interpersonal }\end{array}$ & $\begin{array}{l}\text { Mendengar apa } \\
\text { yang mereka } \\
\text { inginkan }\end{array}$ & $\begin{array}{l}\text { Melayani } \\
\text { bawahan. }\end{array}$ & $\begin{array}{l}\text { mengerti dan } \\
\text { memahami apa } \\
\text { yang } \\
\text { dipimpinnya }\end{array}$ & $\begin{array}{l}\text { Melayani apa } \\
\text { yang menjadi } \\
\text { harapan bapak } \\
\text { ibu }\end{array}$ & $\begin{array}{l}\text { sebaiknya memahami setiap } \\
\text { individu guru }\end{array}$ \\
\hline 3 & $\begin{array}{l}\text { Fungsi kepemimpinan } \\
\text { yang melayani }\end{array}$ & $\begin{array}{l}\text { Kesadaran } \\
\text { Menyadari } \\
\text { kelemahan diri }\end{array}$ & $\begin{array}{l}\text { berkomunikasi } \\
\text { tentang } \\
\text { kebersyukuran } \\
\text { atau keikhlasan }\end{array}$ & $\begin{array}{l}\text { Sabtu } \\
\text { pembinaan guru }\end{array}$ & $\begin{array}{l}\text { berdialog } \\
\text { kinerja }\end{array}$ & diklarifikasi & dialog atau komunikasi \\
\hline
\end{tabular}

Tabel 4.

Analisis Krosek Wawancara Dengan Guru Tentang Pemahaman Kepala Madrasah Yang Melayani

\begin{tabular}{|l|l|l|l|l|l|l|l|}
\hline No. & \multicolumn{1}{|c|}{ Aspek masalah } & \multicolumn{1}{|c|}{ Karakter } & Guru MAN 1 & Guru MAN 2 & Guru MAN 3 & Guru MA DU & \multicolumn{1}{|c|}{ Kesimpulan } \\
\hline 1 & $\begin{array}{l}\text { Definisi kepemimpinan } \\
\text { yang melayani }\end{array}$ & $\begin{array}{l}\text {-Mendengar } \\
\text {-Penerimaan } \\
\text { interpersonal }\end{array}$ & $\begin{array}{l}\text { mengadakan } \\
\text { brefing evaluasi }\end{array}$ & $\begin{array}{l}\text { komunikasi } \\
\text { yang efektif }\end{array}$ & $\begin{array}{l}\text { mengerti } \\
\text { dengan dialog }\end{array}$ & berdialog & $\begin{array}{l}\text { memahami dengan } \\
\text { komunikasi }\end{array}$ \\
\hline 3 & $\begin{array}{l}\text { Fungsi kepemimpinan } \\
\text { yang melayani }\end{array}$ & $\begin{array}{l}\text { Kesadaran } \\
\text { Menyadari } \\
\text { kelemahan diri }\end{array}$ & $\begin{array}{l}\text { pendekatasemu } \\
\text { a guru }\end{array}$ & $\begin{array}{l}\text { mengembangka } \\
\text { n komunikasi }\end{array}$ & $\begin{array}{l}\text { berdialog dan } \\
\text { bersilaturahmi }\end{array}$ & $\begin{array}{l}\text { ngemong" dan } \\
\text { tahu } \\
\text { kelemahannya }\end{array}$ & $\begin{array}{l}\text { mengetahui menyadari } \\
\text { kelemahan diri dengan } \\
\text { komunikasi }\end{array}$ \\
\hline 2 & $\begin{array}{l}\text { Tujuan kepemimpinan } \\
\text { yang melayani }\end{array}$ & $\begin{array}{l}\text { Penyembuhan } \\
\text { Memulihakn emosi }\end{array}$ & $\begin{array}{l}\text { mencari } \\
\text { referensi }\end{array}$ & $\begin{array}{l}\text { kepentingan } \\
\text { peluang masa } \\
\text { depan }\end{array}$ & $\begin{array}{l}\text { bekerja masa } \\
\text { depan }\end{array}$ & $\begin{array}{l}\text { kepentingan } \\
\text { yang akan } \\
\text { datang }\end{array}$ & $\begin{array}{l}\text { bersifat pada tugas } \\
\text { pekerjaannya }\end{array}$ \\
\hline
\end{tabular}

Pengertian mempimpin yang melayani menurut kepala madrasah dari hasil wawancara kepala madrasah diketahui bahwa mereka berupaya untuk mengikuti arti 
kepemimpinan yang telah didefenisikan secara teori namun untuk teori yang digunakan kurang memahami, dan tentang pemahaman tentang model kepemimpinan yang melayani pada keempat madrasah bahwa beberapa kepala madrasah mengetahui model kepemimpinan secara teori namun mereka pada umumnya tidak mengetahui menggunakan model kepemimpinan yang dipergunakan.

Kepemimpinan menurut Greenleaf mempunyai karakter untuk pemyembuhan . yakni Kepala Madrasah dalam pendapatnya tentang kinerja untuk masa lalu atau kinerja yang berpeluang untuk masa depan berdasar hasil wawancara kapala MAN 1 mengikuti program yang kemarin dalam kinerja guru disebabkan merasa masih baru menjabat sebagai kepala madrasah sehingga untuk penyembuhan dan pemulihan emosi belum begitu berimbas nampak, pendekatan dialog tatap muka dengan guru, sedangkan pernyataan hasil wawancara dengan guru dari MA DU Muhammadiyah tentang menolong kesulitan yang dialami guru dalam hal-hal meningkatkan kinerja gur.

Dengan demikian secara umum kepala madrasah berupaya untuk dapat memahami dan mengetahui kelemahan seorang guru yakni melakukan dialog dan komunikasi dan berupaya untuk membantunya yakni mengklarisifikasi permasalahan.

\section{Prinsip-Prinsip Model Kepemimpinan Yang Melayani Terimplementasi Dalam Praktek Kerja Kepala Madrasah}

Dalam kepemimpinan yang melayani terdapat factor-faktor yang mendukung agar kepemimpinan tersebut dapat dikatakan berhasil. Sudarwan Danim (2012:11) menyatakan; adanya pimpinan, pengikut, situasi dan komunikasi.Berikut ini faktorfaktor yang mempengaruhi dalam kepemimpinan yang melayani terimplementasi praktek kerja.

\section{Tabel 5.}

Analisis Wawancara Dengan Kepala Madrasah Tentang Kepemimpinan Yang Melayani

Terimplementasi Dalam Praktek Kerja Kepala Madrasah

\begin{tabular}{|c|c|c|c|c|c|c|c|}
\hline No. & Aspek masalah & Karakter & $\begin{array}{l}\text { Kepala } \\
\text { MAN } 1\end{array}$ & $\begin{array}{l}\text { Kepala } \\
\text { MAN } 2\end{array}$ & $\begin{array}{l}\text { Kepala } \\
\text { MAN } 3\end{array}$ & $\begin{array}{l}\text { Kepala } \\
\text { MA DU }\end{array}$ & Kesimpulan \\
\hline 8 & $\begin{array}{l}\text { Faktor -faktor } \\
\text { kepemimpinan yang } \\
\text { melayani }\end{array}$ & $\begin{array}{l}\text { Membangun } \\
\text { Komunitas: }\end{array}$ & $\begin{array}{l}\text { Supel, belajar yang } \\
\text { terdahulu. }\end{array}$ & $\begin{array}{l}\text { Mengikuti visi dan } \\
\text { misi MAN }\end{array}$ & $\begin{array}{l}\text { memahamikead } \\
\text { aan bapak ibu } \\
\text { guru }\end{array}$ & $\begin{array}{l}\text { ramah } \\
\text {,mengikuti guru }\end{array}$ & $\begin{array}{l}\text { memahami keadaan } \\
\text { sekitar }\end{array}$ \\
\hline 11 & & $\begin{array}{l}\text { Memberikan } \\
\text { arahan }\end{array}$ & $\begin{array}{l}\text { Memberi motivasi tentang } \\
\text { tugas dan } \\
\text { tanggungjawabnya. }\end{array}$ & $\begin{array}{l}\text { Menekankan } \\
\text { tanggungjawab } \\
\text { bersama }\end{array}$ & Tegur binaan & $\begin{array}{l}\text { Dialog dan } \\
\text { komunikasi } \\
\text { dengan baik }\end{array}$ & $\begin{array}{l}\text { komunikasi yang } \\
\text { ramah }\end{array}$ \\
\hline 14 & & $\begin{array}{l}\text { Berperilaku } \\
\text { secara etis }\end{array}$ & Bersyukur tidak mengeluh & Harus panutan & $\begin{array}{l}\text { Ramah dan } \\
\text { contoh. }\end{array}$ & $\begin{array}{l}\text { berakhlak yang } \\
\text { baik }\end{array}$ & $\begin{array}{l}\text { bersikap sesuai } \\
\text { aturan }\end{array}$ \\
\hline
\end{tabular}


Tabel 6.

Analisis Kroscek Wawancara Dengan Guru Tentang Kepemimpinan Yang Melayani

Terimplementasi Dalam Praktek Kerja Kepala Madrasah

\begin{tabular}{|l|l|l|l|l|l|l|l|}
\hline No. & \multicolumn{1}{|c|}{ Aspek masalah } & \multicolumn{1}{|c|}{ Karakter } & \multicolumn{1}{|c|}{ Guru MAN 1 } & Guru MAN 2 & Guru MAN 3 & Guru MA DU & \multicolumn{1}{|c|}{ Kesimpulan } \\
\hline 8 & $\begin{array}{l}\text { Faktor -faktor } \\
\text { kepemimpinan yang } \\
\text { melayani }\end{array}$ & $\begin{array}{l}\text { Membangun } \\
\text { Komunitas: }\end{array}$ & $\begin{array}{l}\text { Komunikasi dengan } \\
\text { berbagai fihak }\end{array}$ & $\begin{array}{l}\text { berkomunikasi dan } \\
\text { bermusyawarah } \\
\text { pada guru }\end{array}$ & $\begin{array}{l}\text { Berbincang dan } \\
\text { berdialog }\end{array}$ & $\begin{array}{l}\text { berkomunikasi } \\
\text { dan } \\
\text { bermusyawarah }\end{array}$ & $\begin{array}{l}\text { membangun } \\
\text { komunitas }\end{array}$ \\
\hline 11 & & $\begin{array}{l}\text { Memberikan } \\
\text { arahan }\end{array}$ & $\begin{array}{l}\text { Tanggungjawab, } \\
\text { amanah dan nilai budaya } \\
\text { kerja }\end{array}$ & $\begin{array}{l}\text { Focus, pengabdian } \\
\text {,layanan }\end{array}$ & $\begin{array}{l}\text { tegur binaan } \\
\text { pelanggaraannya }\end{array}$ & komunikasikan & $\begin{array}{l}\text { komunikasi yang } \\
\text { ramah }\end{array}$ \\
\hline 14 & & $\begin{array}{l}\text { Berperilaku } \\
\text { secara etis }\end{array}$ & Ramah,terbuka & $\begin{array}{l}\text { disiplin, terbuka, } \\
\text { energik, } \\
\text { berwawasan luas. }\end{array}$ & Ramah pengertian & $\begin{array}{l}\text { baik, ramah, } \\
\text { ikhlas }\end{array}$ & ersikap sesuai kode \\
\hline 16 & & $\begin{array}{l}\text { Hubungan } \\
\text { engan orang } \\
\text { lain }\end{array}$ & $\begin{array}{l}\text { Supel, komunikatif } \\
\text { fihak lain }\end{array}$ & $\begin{array}{l}\text { Focus visi misi } \\
\text { madrasah }\end{array}$ & $\begin{array}{l}\text { Komunikatif, } \\
\text { klarifikasi fihak } \\
\text { lain }\end{array}$ & $\begin{array}{l}\text { mengajak untuk } \\
\text { bekerjasama }\end{array}$ & $\begin{array}{l}\text { komunikatif dengan } \\
\text { warga }\end{array}$ \\
\hline
\end{tabular}

Hasil wawancara kepala bahwa kepala madrasah menerapkan nilai-nilai kepemimpinan yang melayani sebagai acuan dalam melaksanakan pekerjaannya. Pelayanan kepala madrasah dalam pekerjaannya ada beberapa yang mendukung dan menghambat, ada pada tabel dibawah ini.

Tabel 7.

Analisis wawancara dengan kepala madrasah yang mendukung kepemimpinan yang melayani

\begin{tabular}{|l|l|l|l|l|l|l|l|}
\hline No. & \multicolumn{1}{|c|}{ Aspek masalah } & Karakter & $\begin{array}{l}\text { Kepala } \\
\text { MAN 1 }\end{array}$ & $\begin{array}{l}\text { Kepala } \\
\text { MAN 2 }\end{array}$ & $\begin{array}{l}\text { Kepala } \\
\text { MAN 3 }\end{array}$ & \multicolumn{1}{c|}{$\begin{array}{c}\text { Kepala } \\
\text { MA DU }\end{array}$} & \multicolumn{1}{c|}{ Kesimpulan } \\
\hline 6 & $\begin{array}{l}\text { Hal-hal yang mendukung } \\
\text { kepemimpinan yang } \\
\text { melayani }\end{array}$ & $\begin{array}{l}\text { member } \\
\text { dayakan }\end{array}$ & $\begin{array}{l}\text { memberi tugas yang belum } \\
\text { pernah dilakukan }\end{array}$ & $\begin{array}{l}\text { Sesuai tupoksinya } \\
\text { masing-masing }\end{array}$ & $\begin{array}{l}\text { Pengimbaskan } \\
\text { guru MGMP }\end{array}$ & $\begin{array}{l}\text { Pasrahkan pada } \\
\text { guru sesuai } \\
\text { dengan } \\
\text { kompetensinya }\end{array}$ & $\begin{array}{l}\text { memberdayakan } \\
\text { sumber daya } \\
\text { seorang guru }\end{array}$ \\
\hline
\end{tabular}

Tabel 8.

Analisis Kroscek Wawancara Dengan Guru Yang Mendukung Kepemimpinan Yang

Melayani

\begin{tabular}{|l|l|l|l|l|l|l|l|}
\hline No. & \multicolumn{1}{|c|}{ Aspek masalah } & Karakter & Guru MAN 1 & Guru MAN 2 & Guru MAN 3 & Guru MA DU & \multicolumn{1}{|c|}{ Kesimpulan } \\
\hline 6 & $\begin{array}{l}\text { Hal-hal yang mendukung } \\
\text { kepemimpinan yang } \\
\text { melayani }\end{array}$ & $\begin{array}{l}\text { member } \\
\text { dayakan }\end{array}$ & Guru diberi pekerjaan baru & $\begin{array}{l}\text { memberi } \\
\text { kesempatan }\end{array}$ & $\begin{array}{l}\text { Mendorong } \\
\text { guru mengikuti } \\
\text { MGMP. }\end{array}$ & $\begin{array}{l}\text { menyerahkan } \\
\text { tugas } \\
\text { tanggungjawab } \\
\text { nya } \\
\text { sepenuhnya. }\end{array}$ & $\begin{array}{l}\text { memberdayakan } \\
\text { sumber daya } \\
\text { seorang guru }\end{array}$ \\
\hline
\end{tabular}

Tabel 9.

Analisis Wawancara Dengan Kepala Madrasah Tentang Menghambat Kepemimpinan

Yang Melayani

\begin{tabular}{|c|l|l|l|l|l|l|l|}
\hline No. & Aspek masalah & Karakter & \multicolumn{1}{|c|}{$\begin{array}{c}\text { Kepala } \\
\text { MAN 1 }\end{array}$} & $\begin{array}{c}\text { Kepala } \\
\text { MAN 2 }\end{array}$ & $\begin{array}{c}\text { Kepala } \\
\text { MAN 3 }\end{array}$ & $\begin{array}{c}\text { Kepala } \\
\text { MA DU }\end{array}$ & \multicolumn{1}{|c|}{ Kesimpulan } \\
\hline 9 & $\begin{array}{l}\text { Hal yang } \\
\text { menghambat } \\
\text { kepemimpinan yang }\end{array}$ & Empati & $\begin{array}{l}\text { Belum semua } \\
\text { nyaman kerja } \\
\text { personal }\end{array}$ & $\begin{array}{l}\text { Belum semua karena } \\
\text { terbatas waktu }\end{array}$ & $\begin{array}{l}\text { Dilakukan pada } \\
\text { beberapa guru }\end{array}$ & $\begin{array}{l}\text { Kasus-kasus } \\
\text { tertentu }\end{array}$ & $\begin{array}{l}\text { Belum dapat } \\
\text { mempengaruhi } \\
\text { seorang guru }\end{array}$ \\
\hline
\end{tabular}




\begin{tabular}{|l|l|l|l|l|l|l|l|}
\hline & melayani & & & & & \multicolumn{1}{l|}{$\begin{array}{l}\text { untuk melakukan } \\
\text { aktifitasnya }\end{array}$} \\
\hline 17 & & Produk/hasil & $\begin{array}{l}\text { Belum maksimal } \\
\text { SDM }\end{array}$ & $\begin{array}{l}\text { Belum memberi } \\
\text { pelayanan pada semua } \\
\text { warga }\end{array}$ & $\begin{array}{l}\text { Belum maksimal } \\
\text { hasil sebagai } \\
\text { contoh/model }\end{array}$ & $\begin{array}{l}\text { Belum } \\
\text { kesejukan dan } \\
\text { kenyamanan } \\
\text { bekerja } \\
\text { diperoleh dari } \\
\text { model } \\
\text { kepemimpinanny } \\
\text { a berupaya sesuai } \\
\text { aturan saja }\end{array}$ \\
& & & & & & \\
& & & & & & \\
\hline
\end{tabular}

Table 10.

Analisis Kroscek Wawancara Dengan Guru Tentang Yang Menghambat Kepemimpinan Yang Melayani

\begin{tabular}{|l|l|l|l|l|l|l|l|}
\hline No. & Aspek masalah & Karakter & Guru MAN 1 & Guru MAN 2 & Guru MAN 3 & Guru MA DU & \multicolumn{1}{|c|}{ Kesimpulan } \\
\hline 9 & $\begin{array}{l}\text { Hal yang menghambat } \\
\text { kepemimpinan yang } \\
\text { melayani }\end{array}$ & Empati & $\begin{array}{l}\text { Belum semua } \\
\text { kebersyukuran }\end{array}$ & $\begin{array}{l}\text { Belum semua yakin akan } \\
\text { kesuksesan acara yang akan } \\
\text { dicapai bersama-sama }\end{array}$ & $\begin{array}{l}\text { Belum semua } \\
\text { mengerti } \\
\text { kegiatan/pekerj } \\
\text { aan dengan } \\
\text { ramah }\end{array}$ & $\begin{array}{l}\text { Belum semua } \\
\text { menghargai } \\
\text { guru atas } \\
\text { potensi }\end{array}$ & $\begin{array}{l}\text { Belum dapat } \\
\text { mempengaruhi } \\
\text { seorang guru } \\
\text { untuk melakukan } \\
\text { aktifitasnya }\end{array}$ \\
\hline 17 & & $\begin{array}{l}\text { Produk/h } \\
\text { asil }\end{array}$ & $\begin{array}{l}\text { Masih belajar untuk } \\
\text { banyakpengalaman } \\
\text { ada hubungan } \\
\text { kerja }\end{array}$ & $\begin{array}{l}\text { Mengajak memaksimalkan } \\
\text { kemampuan yang dimiliki } \\
\text { kepemimpinanny } \\
\text { a berupaya sesuai } \\
\text { aturan }\end{array}$ \\
\hline
\end{tabular}

Dari hasil penelitian bahwa prinsip-prinsip model kepemimpinan yang melayani terimplementasi dalam praktek kerja kepala madrasah, kepemimpinan yang melayani cukup baik dilaksanakan oleh kepala madrasah dalam praktek kerjanya namun masih dalam lingkup tugas pokoknya belum sampai kerja personal setiap guru seperti, empati dan produk dari kepemimpinan yang melayani belum maksimal teratasi.

\section{Peluang Pengembangan Kepemimpinan Yang Melayani Kepala Madrasah}

Kepala madrasah agar kepemimpinan dapat berhasil dengan baik sesuai visi misi dan tujuan dan bekembang maka ada upaya kepemimpinan yang melayani seperti tabel berikut ini.

Tabel 11.

Analisis Wawancara Kepala Madarasah Tentang Upaya Pengembangan Kepemimpinan Yang Melayani Kepala Madrasah

\begin{tabular}{|c|c|c|c|c|c|c|c|}
\hline No. & Aspek masalah & Karakter & $\begin{array}{l}\text { Kepala } \\
\text { MAN } 1\end{array}$ & $\begin{array}{l}\text { Kepala } \\
\text { MAN } 2\end{array}$ & $\begin{array}{l}\text { Kepala } \\
\text { MAN } 3\end{array}$ & $\begin{array}{l}\text { Kepala } \\
\text { MA DU }\end{array}$ & Kesimpulan \\
\hline 5 & $\begin{array}{l}\text { upaya kepemimpinan } \\
\text { yang melayani }\end{array}$ & $\begin{array}{l}\text { Foresight: } \\
\text { menuju masa } \\
\text { depan }\end{array}$ & $\begin{array}{l}\text { Menggali nilai } \\
\text { psikomotornya } \\
\text { yakni bidang } \\
\text { Olahraga } \\
\end{array}$ & $\begin{array}{l}\text { Mengalir sesuai } \\
\text { dengan harapan } \\
\text { bersama }\end{array}$ & $\begin{array}{l}\text { Tantangan nyata } \\
\text { program ketrampilan } \\
\text { siswa. }\end{array}$ & $\begin{array}{l}\text { Mengikuti } \\
\text { guru }\end{array}$ & $\begin{array}{l}\text { mengikuti tuntutan } \\
\text { zaman dan tantangan } \\
\text { nyata }\end{array}$ \\
\hline 19 & & Kehormatan & $\begin{array}{l}\text { berkomunikasi dan } \\
\text { evaluasi kegiatan. }\end{array}$ & $\begin{array}{l}\text { Selalu breffing } \\
\text { atau komunikasi } \\
\text { setiap saat }\end{array}$ & Aktif kemasyarakatan & $\begin{array}{l}\text { Selalu } \\
\text { berdialog }\end{array}$ & $\begin{array}{l}\text { menjaga hubungan } \\
\text { yang baik sebagai } \\
\text { mitra kerja. }\end{array}$ \\
\hline
\end{tabular}


Tabel 12.

Analisis Kroscek Wawancara Guru Tentang Upaya Pengembangan Kepemimpinan

Yang Melayani

\begin{tabular}{|l|l|l|l|l|l|l|l|}
\hline No. & \multicolumn{1}{|c|}{ Aspek masalah } & \multicolumn{1}{|c|}{ Karakter } & Guru MAN 1 & \multicolumn{1}{|c|}{ Guru MAN 2 } & Guru MAN 3 & Guru MA DU & \multicolumn{1}{|c|}{ Kesimpulan } \\
\hline 5 & $\begin{array}{l}\text { upaya kepemimpinan } \\
\text { yang melayani }\end{array}$ & $\begin{array}{l}\text { Foresight: } \\
\text { menuju masa } \\
\text { depan }\end{array}$ & $\begin{array}{l}\text { musyawarah } \\
\text { bersama }\end{array}$ & $\begin{array}{l}\text { Musyawarah } \\
\text { bersama dengan tim } \\
\text { terlebih dahulu }\end{array}$ & $\begin{array}{l}\text { mengikuti hasil } \\
\text { musyawarah } \\
\text { bersama-sama }\end{array}$ & $\begin{array}{l}\text { menginginkan } \\
\text { kebersamaan }\end{array}$ & $\begin{array}{l}\text { keputusan untuk suatu } \\
\text { masa depan dengan } \\
\text { musyawarah }\end{array}$ \\
\hline 19 & & Kehormatan & $\begin{array}{l}\text { berkomunikasi dan } \\
\text { mengingatkan kode } \\
\text { etik kerja }\end{array}$ & $\begin{array}{l}\text { memanfaatkan media } \\
\text { (Washapt ) untuk } \\
\text { bermusyawarah }\end{array}$ & $\begin{array}{l}\text { mengingatkan arti } \\
\text { pentingya } \\
\text { kebersamaan }\end{array}$ & $\begin{array}{l}\text { menjaga adanya } \\
\text { komunikasi } \\
\text { yang baik. }\end{array}$ & $\begin{array}{l}\text { senantiasa menjaga } \\
\text { hubungan yang baik }\end{array}$ \\
\hline 12 & & Kasih Sayang & $\begin{array}{l}\text { Memantau guru } \\
\text { setiap hari }\end{array}$ & $\begin{array}{l}\text { Komunikasi dengan } \\
\text { mengenali guru }\end{array}$ & $\begin{array}{l}\text { berkomunikasi } \\
\text { ramah dalam } \\
\text { bersilaturahmi }\end{array}$ & $\begin{array}{l}\text { Selalu untuk } \\
\text { menyapa ramah } \\
\text { pada guru }\end{array}$ & $\begin{array}{l}\text { Cara komunikasi yang } \\
\text { baik }\end{array}$ \\
\hline
\end{tabular}

Hasil penelitian bahwa peluang pengembangan kepemimpinan yang melayani kepala madrasah baik karena kepala madrasah pada umumnya betujuan untuk masa depan sesuai visinya, selalu menjaga kehormatan jabatan, dan mengupayakan kasih sayangnya dalam melaksanakan tugas dan tanggungjawabnya.

\section{KESIMPULAN}

Pemahaman kepala madrasah tentang kepemimpinan yang melayani di Madrasah Aliyah se Kabupaten Kulon Progo. Pada keempat kepala madrasah secara umum cukup baik.Kepala madrasah mengetahui teori tentang kepemimpinan, namun tentang kepemimpinan yang melayani kepala madrasah tidak mengetahuinya.

Prinsip-prinsip model kepemimpinan yang melayani terimplementasi praktek kerja secara umum cukup baik.Faktor-faktor kepemimpinan yang melayani dapat dilaksanakan cukup baik. Terdapat yang mendukung yakni kepala membedayakan dan menghambat kepemimpinan yakni empati masih belum maksimal. Peluang kepemimpinan yang melayani dapat menjadi berkembang. Hasil menunjukan kepemimimpinan yang melayani Kepala MadrasahAliyah di Kulon Progobaik sikap adanya pengembangan sesuaidengan kompetensi dan indikator-indikator kepemimpinan yang melayani.

\section{DAFTAR PUSTAKA}

Aan Komariah. 2008. Vionary leadership menuju madrasah efektif. Jakarta.Bumi Aksara.

Alben Ambarita. 2015. Kepemimpinan Kepala Madrasah. Yogyakarta Graha Ilmu.Cet 1 Badeni. 2013. Kepemimpinan dan perilaku organiasasi. Bandung. Alfabeta. 
Basrowi dan Sukidin. 2002. Metode Penelitian Kualitatif Perspektif Mikro. Surabaya: Insan Cendikiawan.

Daryanto.2011. Kepala Madrasah sebagai pemimpin pembelajaran.Yogyakarta.Gava media.

Deddy Mulyadi. 2015. Perilaku Orgaisasi dan Kepemimpinan Pelayanan.Badung Alfabeta.

Dierendonck, D.2011, "Servant leadership: A review and synthesis Journal of Management. Vol.37

Greenleaf, R.K. 1970 .The Servant as leader. Westfield, IN: The Greenleaf Center for Servant Leadership.

Iyer Ramajanaki Doraiswamy ..2013. Servant Leadership in Teaching. International Journal of Human Resource Studies.India. Macrothink Institute. Vol. 3, No. 1

Kamus Besar Bahasa Indonesia, Edisi Ketiga, Departemen Pendidikan Nasional, Balai Pustaka, 2000

Miftah Thoha. 2003. Perilaku Organisasi konsep dasar dan aplikasinya.rajawali pers

Moleong Lazy. 2000. Metodologi Penelitian Kualitatif. Bandung. Remaja Rosda Karya

Mulyasa. 2015. Revolosi mental dalam pendidikan. Bandung. Remaja Rosdakarya. cet 1

Noeng Muhajir. 1996. Metode Penelitian Kualiitatif .Yogyakarta. Rake Sarasia.

Peter G. Northouse, 2013. Kepemimpinan teori dan praktik. Jakarta.PT Indeks.cet 1

Pramudyo Anung. 2013. Implementasi Manajemen Kepemimpinan dalam Pencapaian Tujuan Organisasi.Yogyakarta. Jurnal JBMA - Vol. I, No. 2

Sudarwan Danim. 2012. Kepemimpinan pendidikan. Bandung. Alfabeta

Sugiyono.2008. Metode Penelitian Kuantitatif Kualitatif dan R\&D. Bandung. Alfabeta

Suharsimi Arikunto. 1992. Prosedur Penelitian Suatu Pendekatan Praktik. Jakarta. Rineka Cipta

Surahmad Winarno. 1992.Dasar-dasar Tehnik Research. Bandung. Tarsito

Veithal Rivai dan Deddy Mulyadi. 2012. Kepemimpinan dan perilaku organisasi.Jakarta.Rajawali Pres

Wahjosumidjo.2002.Kepemimpinan Kepala Madrasah, Jakarta. Raja Grafindo Persada. 
Wike \& Meily. Mei 2012. Pengaruh Servant Leadership. Jurnal Manajemen Vol. 11 no. 2 